Research Report No. 49/2010

\title{
Jurisprudence and Psychology
}

Dan Priel

Follow this and additional works at: http:/ / digitalcommons.osgoode.yorku.ca/clpe

\section{Recommended Citation}

Priel, Dan, "Jurisprudence and Psychology" (2010). Comparative Research in Law \& Political Economy. Research Paper No. 49/2010. http://digitalcommons.osgoode.yorku.ca/clpe/115

This Article is brought to you for free and open access by the Research Papers, Working Papers, Conference Papers at Osgoode Digital Commons. It has been accepted for inclusion in Comparative Research in Law \& Political Economy by an authorized administrator of Osgoode Digital Commons. 


\section{OSGOODE}

OSCOODE HALL LAW SCHOOL

YOR K UNIVERSITY

\section{OSGOODE HALL LAW SCHOOL}

Comparative Research in Law \& Political Economy

RESEARCH PAPER SERIES

Research Paper No. 49/2010

Jurisprudence and Psychology

Danny Priel

\section{Editors:}

Peer Zumbansen (Osgoode Hall Law School, Toronto, Director, Comparative Research in Law and Political Economy)

John W. Cioffi (University of California at Riverside)

Lisa Philipps (Osgoode Hall Law School, Associate Dean Research)

Nassim Nasser (Osgoode Hall Law School, Toronto,

Production Editor) 


\title{
JURISPRUDENCE AND PSYCHOLOGY Danny Priel*
}

\begin{abstract}
I argue that much of the work in analytic jurisprudence has been concerned with two questions that have not been adequately distinguished: (a) an inquiry about the concept of law, and (b) an explanation of the important features of the practice of law. It is often assumed that the two inquiries are the same. In this essay I distinguish the two and argue that work in psychology provides important insights about both. With regard to the first, I argue that much jurisprudential conceptual analysis is challenged by psychological work on concepts. With regard to the second, I argue that legal theorists would benefit from greater attention to what people's 'internal' attitudes about law are by looking at psychological research on the matter. But psychology is not merely a challenge to contemporary jurisprudence: following the critique I suggest various ways psychological work can assist us in thinking on old jurisprudential questions like the dispute between positivism and natural law or the question of law's normativity.
\end{abstract}

\section{Introduction}

Psychology, the study of the mind, was until late in the nineteenth century considered part of philosophy. An important factor in it gaining independence was when researchers in the field began adopting the experimental methods of the natural sciences. A gulf was thus created between the psychologists who increasingly turned to 'external' means of inquiry and the philosophers who continued to rely on introspection. ${ }^{\mathrm{I}}$ These methods have soon led to opposed substantive paradigms to the explanation of human nature: in psychology behaviourism was the leading theory of the day, in philosophy it was theories that emphasised 'understanding', the examination of the workings of human reason as understood from 'within'.

The behaviourist focus of psychology in those days has led one contemporary psychologist to describe the psychology of the first half of the twentieth century as 'dull, dull, dull' (Pinker, I997, p. 84). This has allowed philosophers to sensibly claim for themselves certain questions that were decidedly of little interest to the mainstream of contemporaneous psychology and for which its methods seemed ill-suited. These ideas have influenced even those philosophers who were not directly interested in the mind. It was,

\footnotetext{
* Visiting Professor, Osgoode Hall Law School, York University (20I0-II); Assistant Professor, University of Warwick School of Law. The essay will appear in a Maksymilian Del Mar (ed.), New Waves in Legal Philosophy (London: Palgrave Macmillan, 20II). Thanks are due to Maks Del Mar, apologies to Paul Gauguin.

I The story, obviously, is a good deal more complicated, but for present purposes it would suffice. For a fuller account see Danziger (1979, I980).
} 
importantly, in those years, that many of the ideas that are now enshrined within mainstream analytic jurisprudence were born.

But then came what is now known as the cognitive revolution. Psychologists (re-)turned to the human mind and have revolutionised our understanding of human nature. It took some time, but the impact of this revolution is now visible all over the social sciences. Law has not been spared. Discussions of legal reasoning, judicial fact-finding and decision-making, have all been the subject of studies that incorporated the new psychological literature. Through its impact on economics psychology has also had a notable impact on economic analysis of law. All this work has shown how cognitive psychology can illuminate and challenge existing ideas. Ultimately, cognitive psychology has also had considerable impact in philosophy, influencing work not just in the philosophy of mind, but also in epistemology and moral philosophy.

Against this background, and based on the mainstream understanding of the tasks of jurisprudence legal philosophers should have been highly interested in these findings. Unlike, say, the division between 'internal', normative moral debate and 'external', descriptive observation of moral attitudes that seems to many-both scientists and moralists - to allow for some sort of entente cordiale in the domain of ethics, the centrality of the descriptive enterprise to contemporary jurisprudence might have suggested that legal philosophers would explore the ways in which the best data available on the human mind could help us understand one of its notable products, the law. But legal philosophers have largely preferred the safety of mulling over ever finer points from a handful of modern classics to examining whether the assumptions underlying those classics are realistic. The purpose of this essay is to suggest some ways in which interest in psychology could illuminate jurisprudential inquiry.

The following discussion is going to be limited in two important respects. On the side of jurisprudence I limit myself to what is known as 'general' jurisprudence, and not to the philosophical investigation of particular legal domain. Perhaps more importantly, I will mostly consider here work that follows Hart and Austin in seeing jurisprudence as a distinct subject, relatively autonomous from moral or political philosophy. The standoff between this approach and the competing view (associated today mostly with Ronald Dworkin) that sees jurisprudence as a branch of political philosophy, has been one of the most notable aspects of jurisprudence of the last half century, but it is one that seems to have reached a stalemate. I will try to show that one advantage of introducing psychology to the domain of jurisprudence is to suggest a way of moving forward in that debate. 
On the side of psychology it must be noted that work in psychology is increasingly supplemented by work in neuroscience and ideas from evolutionary theory. In both areas there have been some attempts to apply these ideas to law, although in both cases they are preliminary and have proven controversial. To limit the scope of my discussion and in order to avoid these more controversial domains, I will ignore this literature here. Even within these limitations, I must stress that the essay is intended as an exploration that and because of space constraints it glosses over many issues that deserve longer treatment.

\section{Where Do We Come From?}

Only with Frege was the proper object of philosophy finally established: namely, first, that the goal of philosophy is the analysis of the structure of thought; secondly, that the study of thought is to be sharply distinguished from the study of the psychological process of thinking; and finally, that the only proper method for analyzing thought consists in the analysis of language. (Dummet, I978, p. 458).

I think that the prejudice against social psychology may have been because psychology itself had great difficulty gaining acceptance in Oxford in particular; Gilbert Ryle was against it .... The humanities dons may have been against since their model of man was of free, rational agents, and they objected to the idea that their thoughts or behaviour could be predicted and explained. (Argyle, 200I, p. 333).

I have been terribly mistrustful of sociology in general. That's an Oxford disease.... (Hart Interview, 2005, p. 289).

Deeply ingrained in the analytic legal philosophy literature that followed Hart's footsteps is an ambivalence towards the social sciences, and a conception of jurisprudence as relatively independent of them. This attitude is most conspicuous not in what one finds in discussions of social scientific work by legal philosophers, but rather by their absence. On the few occasions that such work is discussed, it is most often for the sake of dismissing it as based on shaky foundations or for insisting on its irrelevance for jurisprudential inquiries. $^{2}$

To see this we need to distinguish between two ways of articulating the main project of legal philosophy of the last fifty years. In one what legal philosophers are concerned with is the analysis of concepts like law or obligation. Understood in this way, many legal philosophers have suggested

\footnotetext{
${ }^{2}$ Hart (I994, pp. I93-94); Raz (2009a, pp. I04-05).
} 
that legal philosophy is independent of the social sciences because it is logically prior to them. Call this the priority view. On the priority view the work of legal philosophers is required in order to elucidate the fundamental concepts used in law in order to allow social scientists to be able to answer adequately the questions that they are interested in. On the second conception legal philosophy is concerned with the 'nature' of law or obligation. One way ${ }^{3}$ of articulating the separate domain of jurisprudential inquiry is based on the idea that an explanation of the nature of law must take into account certain features that (so the argument goes) cannot be captured by a scientific explanation. On this view the here philosophy is conceived of as the right way of doing sociology. Those who were baffled by the lack of references to sociological literature or to the absence of any empirical work in a book that purported to be an essay in 'descriptive sociology' have misunderstood Hart's point: it is exactly because on Hart's view the social scientists were too enamoured of the methods of the natural sciences that their work was of little value. Philosophical inquiry, or rather a certain kind of philosophical inquiry, was, if you will, sociology properly so called. Call this the competition view.

The most important idea associated with the competition view is Hart's notion of the 'internal point of view'. And Hart made it clear that at its most abstract this idea stood in direct opposition to the methods of the social sciences, at least to the extent that they adopted the methods of the natural sciences. As he put it, for understanding normative social behaviour the methods of the natural sciences are useless' (Hart, I983, p. 13), exactly because they cannot explain the normative aspect of social behaviour. ${ }^{4}$

Properly understood the priority view and the competition view have different concerns. In the language familiar to legal philosophers the two enterprises may be distinguished as, respectively, analysing the concept LAW and explaining the nature of (the practice of) law. ${ }^{5}$ Unfortunately, the two are rarely kept distinct in the work of legal philosophers. Hart, for example, called his book The Concept of Law but much of the book was concerned with the

3 Not the only one: Raz (2009a, pp. I04-05) has argued that legal philosophy and the sociology of law are distinct because the former deals with the necessary and general while the latter deals with the contingent and particular. But see Priel $2007 \mathrm{~b}$.

${ }^{4}$ Here and elsewhere (Hart, I994, p. 289) Hart follows Winch (I958/1990, pp. 86-94) in positing an unbridgeable chasm between psychological and non-psychological events. $C f$. also Hart and Honoré (I959, p. 50), where the distinction between reasons and causes is drawn. This was a popular view at the time but it was repudiated in Davidson (I963). See also Locke \& Pennington (1982), an article that considers both the philosophical and the psychological literature on the subject.

${ }^{5}$ I follow typographical convention of referring to things in the world (law) in roman letters and to concepts in small capitals (LAW). 
examination of social practices, at one point talking in the same sentence of 'the "essence" or the "nature" or "the definition" of law' (Hart, I994, p. I55; cf. pp. I09, I53) and suggesting they could all be explained by examining legal institutions. Though he starts the book with some analysis of concepts like OBLIGATION, by the time we get to the presentation of the main features of his theory, Hart does not even attempt to demonstrate that it is implicit in anyone's concept LAW. Nor would it likely succeed had he tried: the central ingredients of his account (primary and secondary rules; the rule of recognition) are not (or at least were not) familiar to lawyers at the time. Rather they were classifications imposed on the material by Hart, who thought that such ordering would illuminate certain important aspects of the practice, not the concept. Following him virtually all work in analytic jurisprudence has contained imperceptible blending of talk of the concept LAW and the practice law.

\section{What Are We?}

[U]nlike concepts like 'mass' or 'electron', 'the law' is a concept used by people to understand themselves. We are not free to choose any fruitful concepts. It is a major task of legal theory to advance our understanding of society by helping us understand how people understand themselves. (Raz, I995, p. 237).

I claimed that the work of Hart and his followers has two limbs, one analysis of the concept LAW, the other explanation of law as a practice, and the two are not easily reconciled because their assumptions on the relationship between philosophy and the social science and different and inconsistent. Here I deal with each separately and show how work in psychology challenges both.

\section{Categories, Concepts, and Law}

When people talk about the concept of law, about conceptual analysis of law, what are they talking about? Despite the centrality of this kind of talk in jurisprudence, legal philosophers are surprisingly vague on the matter. But I think the story goes something like this: things (phenomena, events) in the world are members of certain sets according to certain properties they have in common. These sets we call categories. There is also something in (some) people's head, a concept, that refers to things in the world, and that in some ways looks like it is based on those categories. ${ }^{6}$ These concepts are the fundamental units of thought and it is with them that we can understand,

${ }^{6}$ For the distinction between categories and concepts see Murphy (20IO, pp. I3-I4); cf. Jackendoff (I989, p. 69) (distinguishing I-concepts from E-concepts). 
remember, infer and perform the rest of the mental activity that has been important for human survival and that makes humans what they are. The study of concepts, thus, is of great interest, and not surprisingly has been the subject of much psychological work that seeks to understand what concepts are.

Alongside this work philosophy attempts to articulate, explicate, or elucidate the content of concepts, something philosophers do with the aid of familiar philosophical tools like the examination of their intuitions regarding particular cases. Recently, this kind of work, 'conceptual analysis', has come under attack by certain scientifically-minded philosophers for its unreliability. But unlike some other contexts in which the bad reputation of intuitions may be deserved, in this context I think the charge is misguided. Intuitive judgments are nothing more than the examination of the semantic scope of concepts with the aid of particular examples. In a way, there is nothing apart from intuitions one could appeal to here. ${ }^{8}$ The appeal to intuitions in this context is not some illegitimate way of ending a debate; it is simply an indication that there is nothing to debate about. Two people having different intuitions simply indicate they have different concepts. It is true, however (and not always appreciated), that since there is nothing wrong (as opposed to useful) about classifying the world one way or another, debates on such matters are pointless.

But then, what purpose could 'conceptual analysis' possibly serve? In recent years several legal theorists have sought to justify it for helping people 'understand themselves'. ${ }^{9}$ It is in this context that we can understand the appeal to what has been styled 'nonambitious' (Rodriguez-Blanco, 2003, p. I06) or 'modest' (Farrell, 2006, p. 999) conceptual analysis: conceptual analysis in this sense does not aim to 'draw conclusions about what the world is like from how we wield our concepts' (Farrell, 2006, p. 999), only what people think the world is like.

Such an enterprise is not without interest: to the extent that such an inquiry can help bring to light the hidden underlying assumptions that structure individuals' thoughts, such an inquiry can illuminate why people think and behave the way they do (cf. Ewald, I998). Unfortunately, it is exactly this 'modest' version of conceptual analysis that opens it to challenges from psychology and undermines the neat division of labour presented above

7 In legal philosophy this critique has been made by Leiter (2007, p. I80), who cites the work of other philosophers voicing scepticism about intuitions.

${ }^{8}$ Contra Rodriguez-Blanco (2003, p. II3).

9 These words by Raz quoted at the beginning of this section. Similar views are found in Green (I996, p. I7I7); Dickson (200I, p. 40). 
between psychologists (concerned with the nature of concepts in general) and philosophers (concerned with the content of particular concepts). In the last four decades psychologists studying concept possession have posed serious challenges to the model of concepts presupposed by philosophers engaged in conceptual analysis. I consider here some of them very briefly. ${ }^{\text {IO }}$

The way we possess concepts. Much of the conceptual work in jurisprudence is based on the assumption that concepts are possessed as sets of necessary and sufficient features. Though the number of explicit statements to this effect is fairly small (but see Raz, 2009b, pp. 20-2I for a recent example), many of the debates in jurisprudence only make sense on this assumption. A typical way of refuting a suggested analysis of a concept is by offering a counterexample of something that is unquestionably law but does not exhibit one of the supposed necessary conditions of law. The problem is that much psychological research on concept possession has undermined this 'classical' view on concepts (although there is less of a consensus as to what should come in its stead). If psychologists' findings are true, it is hard to see how philosophical style conceptual analysis can be vindicated, and this, ironically, is true particularly conceptual analysis is in its modest guise. Recognizing this some philosophers have sought to maintain the separation between an epistemological-psychological project of dealing with thought and a metaphysical-philosophical project of identifying real world categories to the extent that those have bearings on the content of concepts. It has been argued that all the psychological literature may be, at best, relevant for the former inquiry, it has little bearing on the latter. ${ }^{\text {II }}$ But such arguments will work, at best, on natural kinds concepts, not on law. ${ }^{\mathrm{I}}$

An alternative strategy is to argue that '[c]oncepts, as objects of philosophical study ... are a philosophical creation' (Raz, 2009b, p. I8). As a matter of fact this is false with regard to most contemporary philosophical work on concepts, which is in tandem with psychological studies on concepts. Admittedly, by adopting this (immodest) view of concepts Raz avoids the problem of irreconcilability with psychological work. But thus understood one must wonder whether concepts in this sense exist outside philosophical discourse, how does one identify them, why they should be of any of interest, and how explaining them can assist in humans' self-understanding.

Surveys with a sample of one. Even if we have a valid interest in articulating the boundaries of jurisprudential concepts reliance on intuitions is worrisome,

\footnotetext{
Io See also Harman (I994); Stich (I992, pp. 246-50); Ramsey (I992), all works informed by findings of psychologists.

${ }^{\text {II }}$ See Rey (1983, I985).

${ }^{12}$ Even in this context there are doubts. See Mayr (1992).
} 
not because the method of intuition is itself is wrong, but simply because the numbers of individuals sampled is very small (often one) and that person, because she is usually a university-trained lawyer, may be unrepresentative. (More on this below.) The responses psychologists will illicit from people if surveying them for their concept LAW will be equally be no less (perhaps more) 'intuitive' from those arrived at by philosophical introspection, but their findings will be based on a much larger sample and a more careful methodology. ${ }^{\mathrm{I3}}$

Social and cultural diversity. The point just made is exacerbated when we take cultural and social diversity into account. Much of the work in conceptual analysis is premised on the idea that there is a concept we are elucidating or analyzing. The assumption is, as Hart put it, that in spite of many variations in different cultures and in different times, has taken the same general form and structure' (Hart, I994, p. 240). (Hart talks here about the 'institution' of law, as explained above, he did not distinguish clearly between conoo63epts and practices.) But recent research on the psychology of concepts suggests that different people belonging to different cultures, or even within different social groups within a single culture, possess different concepts designated by the same word (Ross \& Tidwell, 2010; Atran et al., 2005). Raz suggested more recently (2009b, pp. 94-95) that it is 'our' concept of law that legal philosophers seek to explicate, but he has said nothing on the way to individuate 'our' concept from others. (Did the Romans have our concept law? Do contemporary common lawyers have the same concept as contemporary civil lawyers? There does not seem to be a way of answering this question without circularity.) Moreover, psychological research shows that conceptual differences are found even within a single social group. Part of the difference within group will be the result of expertise. Defenders of conceptual analysis often assume that experts (in which they presumably include themselves) have a more complete or less confused view of concepts (Dickson, 2004, pp. 138-9, says so explicitly), but psychological research has shown that experts often have different concepts (e.g., Boster \& Johnson, I989).

The aims of conceptual analysis. A friend of conceptual analysis may reply that philosophical conceptual analysis may still have an aim absent from the work of psychologists. As Farrell put it '[c]onceptual analysis ... attempts to increase our understanding of how we use words. The methodology is employed to clarify and to systematize, to make sense of the way we employ certain important terms by making explicit an underlying, inchoate, but nonetheless

${ }^{13}$ This point is accepted by Jackson (1998, pp. 36-37; 2008), but not (or not explicitly) by his jurisprudential followers, e.g., Rodriguez-Blanco (2003); Farrell (2006). 
coherent concept or theory'. ${ }^{4}$ This seems to resonate with the kind of careful examination of concepts which has been a staple of Western philosophy at least since Socrates, an inquiry that looks very different from the reports collected by social scientists. There are, however, several problems with this suggestion. The first is captured in the words of Raz quoted in the beginning of this section: there is real danger that philosophical work on concepts will not reflect people's attitudes on a concept like LAW, but merely the attitudes of the small group of people who have thought long and hard about the issues. As such the results of their work will be closer to what scientists do when they try to ascertain what electrons are (and note: not what ELECTRONS are). The suggestion that such factually thin inquiry could help people understand themselves seems rather far-fetched. There is real danger that supposedly conceptual debates would not refer to anything about the object of inquiry (Priel, 2008).

To make matters worse, unlike concepts like ELECTRON where some sort of division of linguistic labour exists (Putnam, I975), matters look different in the case of LAW. No doubt there are experts as to the content of laws to which people turn, but it is not clear whether there is such deference with regard to the concept LAW. ${ }^{15}$ This means that when we find competing views about the content of the concept LAW (as we also find about scientific question) we cannot dismiss some of them as mistakes as we can do in the context of scientific concepts. ${ }^{\mathrm{I}}$ All this makes it difficult to see the how conceptual analysis could 'systematize' our concepts. For this reason, to the extent that we wish to draw some conclusions from the concept LAW to the practice (a possibility I discuss below), it is not philosophical conceptual analysis on which we would (or could) rely, but rather political argument.

${ }^{14}$ Farrell (2006, p. Iо०I); and along similar lines Rodriguez-Blanco (2003, pp. IO2-3); $c f$. Strawson (1965, p. 315). I do not discuss here views that seem to be committed to immodest conceptual analysis such as Raz $(2009 \mathrm{~b}$, chs. 2,3$)$. They raise other problems, but I have no space to discuss them here.

Is One can understand certain social clashes over legal matters as resulting from exactly this tension between the lay and the expert concepts of LAw. While non-lawyers are willing to defer to lawyers on matters regarding the content of laws, they often less willing, and therefore enraged, when they perceive legal or social elites adopting a different concept LAW. Since, as I say below, views on the concept LAW affect the content of laws, such differences are not merely 'academic'. For example, on a certain 'legal science' concept of LAW, the attitudes of the public have little or nothing to do with what the law is or should be; not so on a more populist concept, according to which 'true law' reflects the values of the people. Such, all too familiar, disagreement on the concept LAW can have ramifications on what the content of laws is.

${ }^{16}$ Even in the case of scientific concepts the picture is more complex. See Dupré (I98I). 


\section{Practical Reason, Psychology, and the Normativity of Law}

I turn now to the second major limb of general jurisprudence of the last fifty years. Here the focus is on the examination of legal practices. It is in this context that the idea of the internal point of view played a fundamental role in the work of Hart and many others. Rules, Hart argued, have an 'internal aspect', and it is only attention to this internal aspect (which can only be noticed by a theorist adopting the internal point of view) that can account for law's normativity. It is probably the significance given to the internal point of view that has led to the conflation of the examination of the concept of LAW and the role of attitude in the practice of law, for introspection was relevant to both and was being relied upon as a means to answering two distinct questions. Not surprisingly, the two issues became fused and often confused.

But what is the internal point of view and how does it help us understand the practice of law? Hart was emphatic in rejecting any psychological interpretation of the internal point of view. "To feel obliged and to have an obligation are different though often concomitant things. To identify them would be one way of misinterpreting, in terms of psychological feelings, the important internal aspect of rules ...' (Hart, I994, p. 88; also Hart, I983, pp. I66-67). The reason is that there are instances (Hart talks of the 'hardened swindler') of people who are under a legal obligation even though they feel no compulsion to follow it. This, even by Hart's own terms, is less than compelling. That such people exist is not in question, but their views are neither here nor there as far as the internal point of view goes since these people just treat the law as a threat. According to Hart's own theory the reason why such a person is under a legal obligation is because other people take the internal point of view (and as he clarified later they need only have this attitude towards the rule of recognition). The question still remains what the internal point of view consists for those people who do take the internal aspect of rules into account. And about those the puzzle remains: if it is not an emotive attitude, what does the internal point of view add to our understanding of the normativity of legal rules?

Hart's answer, which allowed him to ignore psychology, was social. Threats become (social) rules when they are part of a practice that they are treated 'as a public, common standard of correct judicial decision, and not as something which each judge merely obeys for his part only' (Hart, I994, p. II6, emphasis added). Hart's focus was on the public element in the rules. He explicitly rejected attempts to psychologise the notion of acceptance (pp. 13940) and was insistent that it can be had for all kinds of reasons, even 'the mere wish to do as others do' (p. 203). So he was satisfied with a statement of the form 'This is a valid rule' (p. II7) as an expression of the internal point of view. 
But on this account it remains mysterious what gives this 'normative use of legal language' (p. II7) any normative force. It looks as though Hart says that normativity exists when it exists. ${ }^{17}$ It is not entirely clear why Hart seems satisfied with demonstrating language use and does not delve deeper, but I suspect it is because he thought that as far as the social practice of law is concerned (as opposed to individual beliefs about the moral merit of the law), there is nothing more to explain, and any attempt to say more would entangle the theorist in 'much metaphysics, which few could now accept' (p. I88; cf. p. 84).

Three approaches have emerged in response. Some have thought that Hart's basic approach sound, and that through some elaboration on the idea of convention thought to be implicit in his work we can construct a convincing account of normativity (Postema, I982; Shapiro, 2002). Others found Hart's failure symptomatic of the entire enterprise of trying to explain the normativity of law without appeal to morality. But unlike Hart, they believed that doing so did not involve appeals to any 'spooky' (Dworkin, I978, p. 139) entities. Still others, while accepting Hart's explanation does not work, have maintained that this is because he tried to explain something for which there was no explanation. Law's normativity according to them is nothing but power (Ladenson, I980, pp. I43-45; Griffith, I979, p. I9).

Recent psychological research suggests that there may be another way. This route was perhaps obscured from Hart when psychologists were still under the behaviourist and phenomenalist spell. But work done since then can show the way to a more fruitful understanding of the question of normativity. In a way what I suggest is to do what Hart, ironically, never did: to examine the relations between the concept and the practice, or more specifically to examine the normative pull of the former on the latter.

\section{Where Are We Going?}

There is no such thing as first-person science. (Dennett, 2000, p. 230)

Here I wish to suggest, very tentatively, how what emerges from the discussion so far could lead to jurisprudential theories that take a genuine interest in the work of psychologists and seek to build on them. My argument builds on two

\footnotetext{
${ }^{17}$ Consider: 'a standing recognition (which may be motivated by any of a variety of ultimate reasons' of a commander's words as generally constituting a content-independent peremptory reason for acting is a distinctive normative attitude ... and in my view this is the nucleus of a whole group of related normative phenomena' (Hart, i982, p. 256).
} 
points already mentioned: the need to keep separate the distinction between the concept LAW and the practice law, and the recognition of the way in which, though distinct, they influence each other. What I will seek to demonstrate here is that an important key to answering some of the vexing questions of jurisprudence lies in understanding the difference and relationship between the concept and the practice.

Concepts, according to one (by no means universally accepted) view, must be understood in terms of the role they play within mental theories, 'theories' in the sense that they are part of a network of information about the world (Murphy \& Medin, I985, p. 298; also Medin \& Wattenmaker, I987). To say that concepts cannot be understood outside integrated within theories, and that conceptual coherence is maintained using the application rules on consistency, causal connection and so on. If that is true, then to understand the concept LAW calls for examination of the theory into which it is embedded. Here, I rely on work of social psychologist Tom Tyler, work that set out to identify the attitudes of individuals about the law. Among his finds are that '[p]eople obey the law because they believe that it is proper to do so, they react to their experiences by evaluating their justice or injustice, and in evaluating the justice of their experience they consider factors unrelated to outcome, such as whether they have had a chance to state their case and been treated with dignity and respect' (Tyler, I990, p. I78). This short summary highlights two factors that seem to matter to people in their thinking about law: the fairness of the procedures associated with the promulgation and use of these laws, and their perceived substantive justice.

The findings on procedural justice, though important for understanding certain central ideas about law such as the rule of law, are true of other nonlegal settings as well in non-legal decision-making contexts. But litigation is only part, albeit probably the most visible part, of the law. The second element, the one concerned with substantive justice and moral worthiness of what the law requires, is relevant to law even outside the narrow confines of the courtroom or contacts with other officials.

The question is why are such attributes associated with LAW, even when the practice law often fails to live up to those standards (e.g., Gibson, 2003)? I believe that at least in part the answer has to do with the fact the kind of issues that law normally deals with. This means that even if it is true that legal rules help us by absolving us from the need to decide moral questions on our own, at the same time coming in touch with them primes us to think about the moral considerations that underlie the legal rules thus creating a conceptual association between law and morality. In fact, the extent to which people are willing to defer to the authority of law and refrain from engaging in evaluative 
judgment themselves is itself the product of a judgment that depends on the perceived legitimacy of legal institutions (Tyler, 2006, p. 390). Translated to the language of jurisprudence, the extent to which a legal system may be successful in excluding certain reasons for action may depend on the existence of a more robust moral judgment of its legitimacy.

In some sense the question of the legitimacy of law presented here is merely a reflection of the question of the legitimacy of state coercion directed at one of its more visible manifestations. (Even in this sense it is worth remembering just how much this idea is a product of the modern 'regulatory' state where law is no longer exclusively, or even primarily, concerned with dispute settlements. ${ }^{18}$ ) But it is important to notice that the question of legitimacy is often specific to particular institutions within the apparatus of the state and relates to their composition, organisation and operation. Questions of legitimacy thus have a specific legal flavour in debates over judicial legislation, interpretation of statutes, judicial review and so on. Though these questions are often considered as separate from, and irrelevant to, the questions of 'general' jurisprudence (which is perhaps believed to be general exactly because it does not deal with these questions) there are good reasons for thinking that they are closely tied. There is thus a complex relation between changes in the practice (themselves brought about by societal and technological changes) and changes in the concept. On the one hand the former often lead to change in the latter; on the other, the connection of LAW to legitimacy puts pressure on the limits on the shape that legal institutions can take. If this is true, it is also highly plausible (although a matter that may require empirical evidence in order to validated) that this tie also affects attitudes that impose constraints on the content of laws.

All this suggests the concept LAW denotes not merely a social practice made up of certain familiar institutions (courts, judges, professional bar, prisons) or of certain practices typically thought to take place in these institutions, but also a set of evaluative judgments that tie those institutions to justice, fairness, and through both with legitimising state power. ${ }^{19}$ These considerations are in this way tied to questions about the limits of the law, which in turn call into question the balancing of autonomy and authority. This

I8 To consider just how much the law has changed in this regard consider: 'In the fourteenth century there was no law of England, no body of rules complete in itself with known limits and visible defects; or if there was it was not the property of the common law courts or any others. ... [The lawyer's] business was procedural, to see that disputes were properly submitted to the appropriate deciding mechanism' (Milsom, I98I, p. 83).

I9 Contrast this with the 'structural' features listed in Hart (1994, p. 240), which are derived from focusing on the practice, not the concept. 
characterisation may be parochial in the sense that it was derived from examining only the attitudes of Americans and thus may not completely reflect the attitudes of people elsewhere ${ }^{20}$ but that is a perfectly plausible possibility. The uniformity of the concept LAW needs to be shown, not assumed.

What follows from that? I cannot offer here a full-blown account of what that concept is or its effects on jurisprudential debates, but in what follows I do offer a few suggestions. They are intended to illustrate how the distinction between the concept LAW and the practice law helps us both understand some familiar features of legal discourse and in providing a necessary anchoring in facts to long-standing questions of jurisprudence.

(I) The normativity of law. This ambiguous term is used to discuss several issues. Here I limit myself to the political question of the conditions under which social practice create obligations. At one level, the sociological one if you wish, the existence of beliefs about law's power to create obligation is an important fact for understanding the operation of law. When such beliefs, for whatever reason, disappear legal practices change quite dramatically with them, as is in evidence in an account of law and legality in contemporary Russia (Kurkchiyan, 2003). But significant though this fact is, it might be countered that it cannot, by itself, say much about the question of normativity. As Stephen Perry pithily put it (in a critique directed at Hart), 'believing does not make it so' (Perry, I995, p. I22).

I think the explanation has to take beliefs into account, but not in the simple fashion in which people's (or officials') beliefs that law create obligations make it so. Still, if it is the case that the concept law is associated for most people with the conditions for the legitimate use of force, we have what may be the beginning of an answer. The idea is that certain beliefs about what role law can play in the organisation of society are central to what shape law can take in order to satisfy the requirements of normativity. The question then is what legal institutions need to look like in order to satisfy this role. The question of normativity is thus broken into two components addressing it from two different directions. A successful account on this view is one in which the two components meet. From one end this answer calls for the articulation of the concept law, a job where as we have seen the work of psychologists could prove helpful, although it leaves open additional normative work of sharpening up the concept and of highlighting what it is about this concept that creates the conditions under which a particular social institution could create obligations. From the other, it requires an examination of what legal institutions must satisfy in order to accord with the concept, and, importantly, recognition of

${ }^{20} \mathrm{Cf}$. Brockner et al. (200I) reporting somewhat different attitudes in different countries. 
possibility that this possibility may be realised in different ways. (Notice that in this way the question of the normativity of legal institutions is kept related to but distinct from the question of the normativity of the state.)

An important aspect of this approach, and one that I consider to be an advantage, is that the question of normativity of law cannot be fully answered in the abstract, but only through the examination of the particular arrangements adopted in a particular legal system. On the other hand, the very same feature of this explanation creates the possibility that the answers to these two questions will not meet. The natural assumption is that such a happy meeting can be found, perhaps even must be found. The may be that laws are the only means for ensuring the attainment of certain goods or preventing certain bads, at least in the (contingent) conditions of life in which most people in contemporary Western societies find themselves.

Though such lines of argument are appealing, presenting the question in the way suggested above shows two ways in which an account of the normativity of law may fail. From the first side of the inquiry philosophical anarchists argue that even under the most favourable conditions, no successful argument for the legitimacy of law follows. Translated to the framework suggested here, the argument is that the concept law involves a form of selfdelusion. From the other side, on which I say more in the next paragraph, critical scholars focus more on reality, on the way in which legal institutions work in practice.

(2) The critique of law. It is a familiar feature of legal practice that it is open to normative critique. The most familiar critique, directed especially to particular legal rules, is that they are immoral or unjust. This, on most (although not all) thinkers' view, is an external critique: the legal rule is juxtaposed against the requirement of morality and is criticised for whatever discrepancy exists between the two. But there is a different kind of critique, one that all too often-perhaps by default -is treated as a case of the first kind, but is in fact different. The critique here is that a certain social organisation is "not really' law, even if it has the appearance of legal practice with lawyers, judges, legal jargon and so on.

This sort of critique is best understood as 'internal' in the sense that it seeks to show a divergence between the concept LAW and the practice of law. But it is not a critique that a Hartian account, for all its insistence on the internal point of view, could explain. Typically, such a critique maintains that certain institutions, though they have the appearance of law, are in fact something else, namely politics. ${ }^{21}$ How should such critiques be understood?

${ }^{21}$ It is an indication of the failure of analytic jurisprudence to acknowledge this sort of criticism that the relationship between law and morality (the basis for the first type of criticism of 
Sometimes, they are presented in conceptual terms, backed up by assertions as to what law, or a certain area of law, really is. Such claims point to the ways in which an institution fails to live up to certain values that are tied to individuals' concept LAW.

Thus, for example, a system of social control that fails Fuller's desiderata is often deemed not a legal system. But why? On the Hartian account that equates the concept with the institution the answer has to be this: we examine some unquestionable instances of law and identify their important features. We then compare them to other systems of social control and decide that they are not legal systems simply because they are not sufficiently similar. To the question why those features and not any other are part of the law, there is apparently no answer. But we have empirical evidence that suggests that this explanation is mistaken, since it is considerations of procedural justice, themselves bound to ideas of legitimacy, that are embedded in most people's concept LAW that provide a more plausible explanation of this point.

Similarly, much of the work of critical legal theorists, often thought to have little connection to works within analytic jurisprudence may be understood in this way. ${ }^{22}$ Such works are best understood as arguing that there is a huge gap between the concept and the practice and then either suggesting ways of bridging this gap, or, more pessimistically, claiming that such reform could not succeed and that we should revise our concept instead, as, effectively, Griffith (I979) urged us to do.

(3) Theoretical disagreements. Dworkin pointed out that legal disputes among judges and lawyers are rarely confined to disagreements on boundarydrawing of vague concepts, but rather go to the concepts' core. How are we to make sense of such disagreements? Dworkin offered his answer, but it was one that came with considerable theoretical baggage that many did not wish to carry. But there is an alternative that may explain at least some of the cases: people have different concepts LAW. On a structural account this does not seem plausible, or even relevant, as an explanation of theoretical disagreements of the content of law. But if we recognise that the concept LAW, at least the one that many individuals in Western countries have, is a theory tied to notions of procedural fairness, neutrality, separation of powers, legitimate authority and others, then we have the beginning of an explanation as to where disagreements come from, and why, when they occur, they tend to be global. (This point also shows why Dworkin is right to blur the line between 'law' and

law) has been the subject of endless discussion, whereas the relationship between law and politics (the basis of the second type of criticism) has received much less attention.

${ }^{22}$ This is connected to the idea of 'immanent critique', which has strong connections with critical legal studies. See Hunt (I987, pp. I0-I6). 
'the law': differences in the concept LAW will often have an effect on 'the law' of individual cases.) Many disagreements can be traced to different views on those evaluative questions, which in turn affect different people's concept LAW.

(4) Legal positivism or natural law? Both and neither. The argument presented here is meant to be broadly naturalistic, both in seeking to ground its arguments in facts and in suggesting that such facts are relevant for explaining some of the normative aspects of law. There is a tempting assumption that naturalism entails, or is in some other way closely associated with, legal positivism (Leiter, 2007 , ch. 4), but in fact most contemporary legal positivist theories are quite strongly opposed to such ideas (Priel, forthcoming). The account outlined here may be able to bridge the gap by offering a naturalist theory of natural law. It is, of course, an unusual kind of natural law, one that many card carrying natural lawyers may well wish to dissociate themselves from: it says little about reason and less about God; and unlike secular versions of natural law it does not presuppose the existence of objective morality. But it also departs from many of the features that have been the hallmark of legal positivism and accepts certain fundamental features of natural law. First, it denies the view that an adequate explanation of legal phenomena is nothing more than an account of the practice. This is found in Bentham who said that 'law ... taken indefinitely, ... when it means any thing, can mean nothing more nor less than the sum total of a number of individual laws taken together' (Bentham I996, p. 294 [ $\ I 7.23]$ ), and, as I have argued above, despite appearances, this is also the main focus of Hart's account. Second, it countenances (and has a straightforward explanation for) something like the proposition 'unjust law is not law', now reformulated as 'unjust law is not LAW'. Third, it shows a connection between law and political and moral values; it recognises that since reliance on such moral and political values is necessary, and since there is no way that such values may be simply described, a theory of law will not be morally neutral; fourth, it can explain the way changes in these values will result in changes in the laws of a given state. It thus rejects the view strongly tied with contemporary legal positivism that separates general jurisprudence from questions about the content of legal norms. Finally, the view developed here enables us to have a different location for examining the connection between law and morality. Due to the influence of legal positivism, the debate was largely confined to the domain of legal validity. But the view developed here suggests a new 'location' for examining the connections, already mentioned, between the concept LAW and morality. 
(5) Changing the aims of jurisprudence. Jurisprudence has been obsessed with the elusive aim of describing law for quite some time now. ${ }^{23}$ One way of understanding the current essay is as an attempt to offer some suggestions as to how a more empirically grounded inquiry could make such an enterprise more plausible. But philosophy could at best play only a secondary role in such an inquiry for which the methods of the social sciences (including psychology) are clearly superior to those of analytic philosophy. To the extent that jurisprudents are interested in maintaining a philosophical project (broadly conceived) its focus should be different. One way of doing this is by relying on psychology for the sake of better informing their views on what law can and cannot effectively do, which may be relevant to the question what it should and should not do. Another is by highlighting, as I have tried here, the role of ideals within jurisprudence. This is an inquiry with a long history (e.g., Cohen, 1936). What I say here may be understood as an attempt to modernise this inquiry and put it on firmer empirical grounds.

\section{Conclusion}

A naturalistic jurisprudence will have to incorporate within itself the best of current information and interpretation from psychology and psychiatry and it will have to go beyond that to a formulation of problems surmising of results within realms that the conventional mind would not admit to be legal at all. (Robinson, I935, p. 76)

Jurisprudence—or, more precisely, the theory of adjudication—is "naturalized" because it falls into place, for the Realist, as a chapter of psychology (or anthropology or sociology). (Leiter, 2007, p. 40)

One quote coming from the heyday of legal realism, the other, three generations later, from a contemporary defender, expresses the same idea, even employing similar terminology. ${ }^{24}$ Central to both is the idea that a more naturalistic approach to jurisprudence, one grounded in empirical work, could prove illuminating, and it is a view I am sympathetic with (Priel, forthcoming). In applying this idea, however, the two authors seem to take a different route. The former quotation, written by a psychologist, comes from a book that put

${ }^{23}$ Criticised in Priel (2007a, 2010).

${ }^{24}$ I do not claim that Robinson and Leiter's respective ideas are identical; there is considerable difference in focus between the two books, and the seventy-odd years between them clearly show their mark. Nonetheless, the basic idea of naturalistic jurisprudence is very similar. It is therefore odd that Leiter, in his single reference to Robinson, aligns him to what he calls the anti-scientific, 'sociological wing' of the realists along with Jerome Frank and Joseph Hutchinson (Letier, 2007, p. 35). 
particular emphasis on the value of psychology to lawyer; the latter quotation, by contrast, comes from a book that displays a more ambivalent attitude towards psychology. Despite the nod to psychology in the quote above, in explaining what naturalised jurisprudence would look like Letier seems sympathetic to work in which 'deterministic causes rule, and in which volitional agency plays little or no explanatory role' (Leiter, 2007, p. I35). ${ }^{25} \mathrm{I}$ do not question that such work offers valuable insights, but it is hard to see what legal philosophers could contribute to it. In this essay I suggested ways in which the naturalistically-inclined legal philosopher could use psychological literature to get a better grasp of the foundational questions of jurisprudence without thereby giving up the subject altogether.

\section{References}

M. Argyle (200I) 'The Development of Social Psychology in Oxford' in G.C. Bunn et al. (eds.) Psychology in Britain: Historical Essays and Personal Reflections (Leicester: BPS Books) 333-43.

S.L. Armstrong et al. (1983) 'What Some Concepts Might Not Be', Cognition, XIII, 263-308.

S. Atran et al. (2005) 'The Cultural Mind: Environmental Decision Making and Cultural Modeling within and across Populations', Psychological Review, CXII, 744-76.

J. Bentham. I996 (1780/89). An Introduction to the Principles of Morals and Legislation (Oxford: Oxford University Press).

J.S. Boster \& J.C. Johnson (I989) 'Form or Function: A Comparison of Expert and Novice Judgment of Similarity among Fish', American Anthropologist, XCI, 866-89.

J. Brocker et al. (200I) 'Culture and Procedural Justice: The Influence of Power Distance Reactions to Voice', Journal of Experimental Social Psychology, XXXVII, 300-I5.

M.R. Cohen (1936) 'On Absolutisms in Legal Thought', University of Pennsylvania Law Review, LXXXIV, 68I-7I5.

K. Danziger (I979) 'The Positivist Repudiation of Wundt', Journal of the History of the Behavioral Sciences, XV, 205-30.

${ }^{25}$ Leiter's views are less than perspicuous on the matter. The quoted commitment to research from the external point of view, which Leiter associates with 'hard positivism' must be read with his claim (p. I88) that this work 'relies centrally on Hemeuntic Concepts' and on the truth of the 'Legal Model' (p. I89), but it is not clear to me how. Similarly, at one point he says that the 'political science literature' literature that it 'has not been much more successful' (p. ${ }^{6} 6$ ) than alternative explanations, while elsewhere he says about the very same literature that it 'ha[s] often fared better' (p. 135) than them. 
K. Danziger (I980) 'The History of Introspection Reconsidered', Journal of the History of the Behavioral Sciences, XVI, 24I-62.

D. Davidson (1963) 'Reasons, Actions, and Causes', Journal of Philosophy, LX, 685-700.

D.C. Dennett (200I) 'Are We Explaining Consciousness Yet?', Cognition, LXXIX, 22I-37.

M.K. Dhami (2003) 'Psychological Models of Professional Decision Making', Psychological Science, XIV, I75-80.

J. Dickson (200I) Evaluation and Legal Theory (Oxford: Hart Publishing).

J. Dickson (2004) 'Methodology in Jurisprudence: A Critical Survey', Legal Theory, X, II7-56.

M. Dummett (1978) Truth and Other Enigmas (Cambridge: Harvard University Press).

J. Dupré (I98I) 'Natural Kinds and Biological Taxa', Philosphical Review, $\mathrm{XC}$, 66-90.

W. Ewald (I998) 'The Jurisprudential Approach to Comparative Law: A Field Guide to "Rats", American Journal of Comparative Law, XLVI, 7OI-7.

I.P. Farrell (2006) 'H.L.A. Hart and the Methodology of Jurisprudence', Texas Law Review, LXXIV, 983-IoII.

J.L. Gibson, 'Russian Attitudes towards the Rule of Law: An Analysis of Survey Data' in Denis J. Galligan \& Marina Kurkchiyan (eds.), Law and Informal Practices: The Post-Communist Experience (Oxford: Oxford University Press) 77-9I.

J.A.G. Griffith (I979) 'The Political Constitution', Modern Law Review, XLII, I-2I.

G. Harman (1994) 'Doubts about Conceptual Analysis' in Michaelis Michael and John O'Leary-Hawthorne (eds.), Philosophy in Mind: The Place of Philosophy in the Study of Mind (Dodrecht: Kluwer Academic Publishers) 43-48. Press).

H.L.A. Hart (1994) The Concept of Law, 2nd edn (Oxford: Clarendon

H.L.A. Hart (1982) Essays on Bentham (Oxford: Clarendon Press).

H.L.A. Hart (I983) Essays in Jurisprudence and Philosophy (Oxford: Clarendon Press).

'Hart Interviewed: H.L.A. Hart in Conversation with David Sugarman' (2005) 32 Journal of Law and Society 267-93 (cited as 'Hart Interview').

H.L.A. Hart and A.M. Honoré (I959) Causation in the Law (Oxford: Clarendon Press).

A. Hunt (I987) "The Critique of Law: What is "Critical" about Critical Legal Theory', Journal of Law and Society, XIV, 5-I9. 
R. Jackendoff (I989) 'What is a Concept that a Person May Grasp It', Mind and Language, IV, 68-102.

F. Jackson (1998) From Metaphysics to Ethics: A Defence of Conceptual Analysis (Oxford: Clarendon Press).

F. Jackson (2008), Book review of Joshua Knobe \& Shaun Nichols, eds., Experimental Philosophy (New York: Oxford University Press, 2008), Notre Dame Philosophical Reviews, http://ndpr.nd.edu/review.cfm?id=I4828.

M. Kurkchiyan (2003) 'The Illegitimacy of Law in Post-Soviet Societies', in Denis J. Galligan \& Marina Kurkchiyan (eds.), Law and Informal Practices: The Post-Communist Experience (Oxford: Oxford University Press) 25-46.

R. Ladenson (I980) 'In Defense of a Hobbesian Conception of Law' Philosophy and Public Affairs, IX, I34-59.

B. Leiter (2007) Naturalized Jurisprudence: Essays on American Legal Realism and Naturalism in Legal Philosophy (Oxford: Oxford University Press).

D. Locke \& D. Pennington (I982) 'Reasons and Other Causes: Their Role in Attribution Processes', Journal of Personality and Social Psychology, XLII, 2I223.

A.D. Martin et al. (2004) 'Competing Approaches to Predicting Supreme Court Decision Making', Perspectives on Politics, II, 76I-7.

E. Mayr (1992) 'Species Concepts and their Application' in Marc Ereshefsky (ed.), The Units of Evolution: Essays on the Nature of Species (Cambridge: MIT Press) I5-26.

J. Mikhail (2007) "Plucking the Mask of Mystery from Its Face": Jurisprudence and H.L.A. Hart' Georgetown Law Journal, XCV, 733-79.

D.L. Medin \& W.D. Wattenmaker (I987) 'Category Cohesiveness, Theories, and Cognitive Archeology' in U. Neisser (ed.) Concepts and Conceptual Development: Ecological and Intellectual Factors in Categorization (New York: Cambridge University Press) 25-62.

S.F.C. Milsom (I98I) Historical Foundations of the Common Law, and edn (London: Butterworths).

G.L. Murphy, 'What Are Categories and Concepts?' in D. Mareschal et al. (eds.), The Making of Human Concepts (New York: Oxford University Press, 20IO) II-28.

G.L. Murphy \& D.L. Medin (1985) 'The Role of Theories in Conceptual Coherence' Psychological Review, XCII, 289-3i6.

S.R. Perry (1995) 'Interpretation and Methodology in Legal Theory' in A. Marmor (ed.), Law and Interpretation: Essays in Legal Philosophy (Oxford: Clarendon Press, I995) 97-I35.

S. Pinker (1997) How the Mind Works (London: Penguin). 
G.J. Postema (I982) 'Coordination and Convention at the Foundation of Law', Journal of Legal Studies, XI, I65-203.

D. Priel (2007a) 'Evaluating Descriptive Jurisprudence', American Journal of Jurisprudence, LII, I39-58.

D. Priel, (2007b) 'Jurisprudence and Necessity', Canadian Journal of Law and Jurisprudence, XX, I73-200.

D. Priel, (2008) 'The Boundaries of Law and the Purpose of Legal Philosophy' Law and Philosophy, XXVII, 643-95.

D. Priel (20I0) 'Description and Evaluation in Jurisprudence', Law and Philosophy, XXIX, 633-667.

D. Priel (forthcoming 20II) 'Jurisprudence between Science and the Humanities', Washington University Jurisprudence Review, III, available at http://ssrn.com/abstract=I566858.

H. Putnam (1975) 'The Meaning of "Meaning"' in Mind, Language, and Reality: Philosophical Papers Volume 2 (Cambridge: Cambridge University Press, I975) 2I5-7I.

W. Ramsey (I992) 'Prototypes and Conceptual Analysis', Topoi, XI, 59-70.

J. Raz (1995) Ethics in the Public Domain: Essays on the Morality of Law and Politics, revised edn (Oxford: Clarendon Press).

J. Raz (2009a) The Authority of Law: Essays on Law and Morality, 2nd edn (Oxford: Oxford University Press).

J. Raz (2009b) Between Authority and Interpretation (Oxford: Oxford University Press).

G. Rey (I983) 'Concepts and Stereotypes', Cognition, XV, 237-62.

G. Rey (I985) 'Concepts and Conceptions: A Reply to Smith, Medin and Rips', Cognition, XIX, 297-303

E.S. Robinson (I935) Law and the Lawyers (New York: Macmillan).

V. Rodriguez-Blanco (2003) 'A Defence of Hart's Semantics as Nonambitious Conceptual Analysis', Legal Theory, IX, 99-I24.

N. Ross \& M. Tidwell, 'Concepts and Culture', in Denis Mareschal et al. (eds.), The Making of Human Concepts (New York: Oxford University Press, 20I0) I3I-48.

S.J. Shapiro (2002) 'Law, Plans, and Practical Reason', Legal Theory, VIII, 387-44I.

S. Stich (I992) 'What is a Theory of Mental Representation?', Mind, CI, 243-26I.

P.F. Strawson (1965) 'Analysis, Science, and Metaphysics', in Richard Rorty, ed., The Linguistic Turn: Essays in Philosophical Method (Chicago: University of Chicago Press) 3I2-20. 
T.R. Tyler (I990) Why People Obey the Law (New Haven, Yale University Press).

T.R. Tyler (2003) 'Procedural Justice, Legitimacy, and the Effective Rule of Law', Crime and Justice, XXX, 283-357.

T.R. Tyler (2006) 'Psychological Perspectives on Legitimacy and Legitimation', Annual Review of Psychology, LVII, 375-400.

P. Winch (I990) The Idea of a Social Science and Its Relation to Philosophy, 2nd edn (London: Routledge) (first edition i958). 